Citation: T. Elbeaino, M. Cara, S. Shahini, P. Pandeli (2021) Detection and phylogeny of viruses in native Albanian olive varieties. Phytopathologia Mediterranea 60(1): 165-174. doi: 10.36253/ phyto-11985

Accepted: January 30, 2021

Published: May 15, 2021

Copyright: @ 2021 T. Elbeaino, M. Cara, S. Shahini, P. Pandeli. This is an open access, peer-reviewed article published by Firenze University Press (http:// www.fupress.com/pm) and distributed under the terms of the Creative Commons Attribution License, which permits unrestricted use, distribution, and reproduction in any medium, provided the original author and source are credited.

Data Availability Statement: All relevant data are within the paper and its Supporting Information files.

Competing Interests: The Author(s) declare(s) no conflict of interest.

Editor: Nihal Buzkan, Kahramanmaras Sütçü Imam University, Turkey.

\section{Short Notes \\ Detection and phylogeny of viruses in native Albanian olive varieties}

\author{
Toufic ElbeainO ${ }^{1, *}$, Magdalena CARA², Shpend SHAHini ${ }^{2}$, Pasko \\ PANDELI ${ }^{1}$ \\ ${ }^{1}$ Istituto Agronomico Mediterraneo di Bari, Via Ceglie 9, 70010 Valenzano (BA), Italy \\ ${ }^{2}$ Agricultural University of Tirana, Department of Plant Protection, Albania \\ ${ }^{*}$ Corresponding author. E-mail: elbeaino@iamb.it
}

Summary. Forty samples representing 14 native Albanian and two foreign olive varieties were collected from an olive varietal collection plot in the Valias region (Tirana, Albania). The samples were assayed by RT-PCR for presence of olive-infecting viruses, including arabis mosaic virus (ArMV), cherry leaf roll virus (CLRV), cucumber mosaic virus (CMV), olive latent ringspot virus (OLRSV), olive latent virus 1 (OLV-1), olive leaf yellowing-associated virus (OLYaV), strawberry latent ringspot virus (SLRSV) and by PCR for the bacterium Xylella fastidiosa (Xf). Ninety-eight percent of the samples were infected with at least one virus. OLYaV was the most prevalent (85\% of samples), followed by OLV-1 (50\%), OLRSV (48\%), CMV (28\%), SLRSV (3\%) and CLRV (5\%), whereas ArMV and Xf were absent. Fifty-five percent of the samples were infected with one virus, $13 \%$ with two viruses, $20 \%$ with three, and 5\% with four. Analyses of the nucleotide sequences of the Albanian virus isolates generally showed low genetic variability, and that most were phylogenetically related to Mediterranean isolates, in particular to those from Greece and Italy. Five olive trees, representing three native cultivars ('Managiel', 'Kalinjot' and 'Kushan-Preze') and one foreign ('Leccino'), were found to be plants of the Conformitas Agraria Communitatis ("CAC") category i.e. free of ArMV, CLRV, SLRSV and OLYaV. Only one tree of the native cultivar 'Ulliri i kuq' was free of all tested viruses, so this is plant material of the "Virus-tested" category. Olives derived from both categories could be used for propagation of standard quality plant materiel in a future certification programme for olive in Albania. This is the first report of CLRV, OLRSV, CMV and OLV-1 in Albania. The study also reveals the precarious health status of native olive varieties in the Valias varietal collection plot. However, the discovery of six plants representing two certifiable categories is a first step in a future olive tree certification program in the country.

Keywords. RT-PCR, sequence and phylogenetic analyses, certification programme.

\title{
INTRODUCTION
}

Olive (Olea europaea) is one of the oldest and most important fruit tree crops in Albania (Belaj et al., 2003). Currently, there are 54,000 ha of olive groves containing approx. 10 million trees in Albania, of which thousands are secular (Ismaili, 2009). The olive growing area in this country extends 
from the northern border of Shkoder to Konispol in the south, penetrating the mainland towards the east, through river valleys, creating a continuum of olive groves (Velo and Topi, 2017). Until 2009, the olive groves were distributed as follows: $10 \%$ on flat land, $83 \%$ on hillsides and 7\% in steep areas (MAFCP, 2009); however, this situation has changed in favour of flat land and hilly areas making olive cultivation a dominant feature of the landscapes (Kolaj et al., 2017).

Most olive production in Albania is concentrated in the coastal and mountainous areas (Fier, Berat, Elbasan and Vlora regions) with Mediterranean climatic conditions. In 2018, almost 100,000 tons of olives were produced, an increase of $3.2 \%$ compared to previous years, and the olive oil industry produced 6,000 tons of product (Lazemetaj, 2018).

The genetic resources of Albanian olive groves are varied, with many ancient native varieties (approx. 50 varieties), but only six ('Kalinjot', 'Krypsi Beratit', 'Bardhi Tiranë', 'Krypsi Elbasanit', 'Mixan' and 'Himara') make up $85 \%$ of the national production (MoA, 2017). Olive tree propagation is mainly by grafted or self-rooted cuttings, which undergo a Conformitas Agraria Communitatis ("CAC") certification. This is based on visual assessment of the health status of the olive tree and is managed by the "National Seed and Plant Institute" of the Ministry of Agriculture (MoA). To preserve Albanian olive germplasm, the MoA with the collaboration of the Agricultural University of Tirana has established a varietal collection plot in the Valias region of Albania. This plot contains the most important native varieties (Genetic Bank of the University of Tirana, Albania). Initially, these "mother" plants of different varieties were selected based on visual inspections, regardless of their phytosanitary status.

Although this approach can be valid for excluding some diseases, it is not appropriate for virus infections which can be masked in plants in latent forms andlor at low concentrations, thus leading to the selection of false virus-free olive trees. As with other crops, propagation of olive by vegetative means favours virus spread. Olive is affected by 15 viruses (Martelli, 2013), some of which are agents of identified diseases, while most cause latent infections, the effects of which have yet to be determined.

Three surveys of virus diseases (Saponari et al., 2002; Çakalli et al., 2006; Luigi et al., 2009), carried out on, respectively, 38, 37 and 50 trees, have summarized knowledge on olive viruses present in Albania. Only strawberry latent ringspot virus (SLRSV) and olive leaf yellowing-associated virus (OLYaV) were identified. Following the growing interest of farmers in the use of high-quality nursery plants, identification of healthy plants that can be used as a sources of propagation material for growers has become a necessity to improve the national olive industry. Albania has therefore started a certification programme for the multiplication of olive plant material. As part of this programme, a survey was conducted in the varietal collection plot of "mother" plants (in the Valias region) to assess the virus phytosanitary status of native varieties that could be used in the future. Furthermore, the recent outbreak of the olive quick decline syndrome, caused by Xylella fastidiosa (Xf) in Italy (Saponari et al., 2013), and its identification in other European countries (France, Spain, Germany) made it necessary to extend this investigation to survey for this bacterium, for which the results of both studies are reported in the present paper.

\section{MATERIALS AND METHODS}

\section{Field survey and source of plant material}

In March 2018, a survey was conducted in a plot for the varietal collection of olive (Valias, Tirana, Albania) which was established by the Albanian Ministry of Agriculture to include the most important olive varieties in the country. The olive germplasm in this plot has been periodically subjected to phenotypic and pomological evaluations in order to identify trees that could be used as propagation material in the Albanian certification programme.

Forty olive trees with no apparent symptoms were each sampled. Leaves and cuttings (approx. 25-30 cm long) aged between 1 and 2 years, were taken from each tree canopy. In total, 16 cultivars were sampled, of which 14 were native and two were foreign (Table 1).

Three clones of each cultivar were sampled, and the samples were labelled, stored in plastic bags at $4^{\circ} \mathrm{C}$ and brought to the laboratory for analysis. Cuttings from olive seedlings kept in screenhouses at the Mediterranean Agronomic Institute of Bari, which were healthy as indicated by RT-PCR assays were used as negative control samples, and different plants infected (also indicated by RT-PCR) with arabis mosaic virus (ArMV), cherry leaf roll virus (CLRV), cucumber mosaic virus (CMV), olive latent ringspot virus (OLRSV), olive latent virus 1 (OLV-1), OLYaV and SLRSV, were used as positive control samples.

\section{Extraction of total nucleic acids}

For virus detection, total nucleic acids (TNAs) were extracted from $0.2 \mathrm{~g}$ of phloem tissues of each sample 
Table 1. Olive samples collected from the varietal collection plot of Valias region (Tirana, Albania), assayed by RT-PCR for the presence of seven olive-infecting viruses. ${ }^{*}$ indicates $C A C$ category plants; ${ }^{* *}$ indicates Virus-tested category plant.

\begin{tabular}{|c|c|c|c|c|c|c|c|c|c|}
\hline Cv. $\mathrm{N}^{\circ}$ & Cultivar & Sample $N^{\circ}$. & ArMV & SLRSV & CLRV & OLYaV & OLRSV & $\mathrm{CMV}$ & OLV-1 \\
\hline \multirow[t]{3}{*}{1} & Boç & 1 & - & - & - & + & + & - & - \\
\hline & & 2 & - & - & - & + & + & - & - \\
\hline & & 3 & - & - & - & + & + & - & - \\
\hline \multirow[t]{2}{*}{2} & Managjel & $1^{*}$ & - & - & - & - & + & - & + \\
\hline & & 2 & - & - & - & + & + & - & + \\
\hline \multirow[t]{3}{*}{3} & Frangu & 1 & - & - & - & + & - & - & + \\
\hline & & 2 & - & - & - & + & - & - & + \\
\hline & & 3 & - & - & - & + & - & - & + \\
\hline \multirow[t]{3}{*}{4} & Kushan & 1 & - & - & - & + & - & - & + \\
\hline & & 2 & - & - & - & + & + & - & + \\
\hline & & 3 & - & - & - & + & - & - & + \\
\hline \multirow[t]{3}{*}{5} & I bardhi i Tiranes & 1 & - & - & - & + & + & - & + \\
\hline & & 2 & - & - & - & + & + & - & + \\
\hline & & 3 & - & + & - & + & + & - & + \\
\hline \multirow[t]{3}{*}{6} & Kalinjot & $1^{\star}$ & - & - & - & - & + & + & - \\
\hline & & $2^{*}$ & - & - & - & - & - & + & - \\
\hline & & 3 & - & - & - & + & - & + & - \\
\hline \multirow[t]{3}{*}{7} & Krypsi i Krujes & 1 & - & - & - & + & + & + & - \\
\hline & & 2 & - & - & + & + & + & + & - \\
\hline & & 3 & - & - & - & + & + & - & - \\
\hline \multirow[t]{3}{*}{8} & Kokermadhi i Beratit & 1 & - & - & + & + & - & + & - \\
\hline & & 2 & - & - & - & + & - & + & + \\
\hline & & 3 & - & - & - & + & - & + & + \\
\hline \multirow[t]{3}{*}{9} & I holli i Himares & 1 & - & - & - & + & + & - & - \\
\hline & & 2 & - & - & - & + & + & - & - \\
\hline & & 3 & - & - & - & + & + & - & - \\
\hline \multirow[t]{3}{*}{10} & Mixan & 1 & - & - & - & + & - & + & - \\
\hline & & 2 & - & - & - & + & - & - & + \\
\hline & & 3 & - & - & - & + & - & + & - \\
\hline \multirow[t]{3}{*}{11} & Lecino Valias & 1 & - & - & - & + & + & - & - \\
\hline & & 2 & - & - & - & + & - & - & - \\
\hline & & $3^{*}$ & - & - & - & - & - & - & + \\
\hline \multirow[t]{2}{*}{12} & Frantoio-Valias & 1 & - & - & - & + & + & - & - \\
\hline & & 2 & - & - & - & + & + & + & + \\
\hline \multirow[t]{2}{*}{13} & Kushan-Preze & $1^{*}$ & - & - & - & - & - & - & + \\
\hline & & 2 & - & - & - & + & - & - & + \\
\hline \multirow[t]{2}{*}{14} & I bardhi i Tiranes-Preze & 1 & - & - & - & + & - & - & - \\
\hline & & 2 & - & - & - & + & - & - & + \\
\hline 151 & Mixan-Preze & 1 & - & - & - & + & - & - & + \\
\hline \multirow[t]{3}{*}{16} & Ulliri i kuq-Preze & $1^{\star *}$ & - & - & - & - & - & - & - \\
\hline & Number of infected trees & & 0 & 1 & 2 & 34 & 19 & 11 & 20 \\
\hline & $\%$ infected trees & & $\mathbf{0}$ & 2.5 & 5 & 85 & 47.5 & 27.5 & 50 \\
\hline
\end{tabular}


(cortical scrapings). Each sample was homogenized in $1 \mathrm{~mL}$ of grinding buffer $(0.4 \mathrm{M}$ guanidine thiocyanate, $0.2 \mathrm{M} \mathrm{NaOAc}$ (pH 5.2), $25 \mathrm{mM}$ EDTA, 1.0 M KOAc (pH 5.0), and $2.5 \% \mathrm{w} / \mathrm{v}$ PVP-40). Nucleic acids were then purified with silica particles (Foissac et al., 2001).

For Xf detection, DNA was extracted following the CTAB protocol ( $2 \%$ hexadecyl trimethyl-ammonium bromide, $0.1 \mathrm{M}$ Tris- $\mathrm{HCl}$ (pH 8), $20 \mathrm{mM}$ EDTA, and 1.4 $\mathrm{M} \mathrm{NaCl}$ ) (Hendson et al., 2001). For each sample, $0.3 \mathrm{~g}$ of fresh leaf midrib and petiole was homogenized with $2 \mathrm{~mL}$ of CTAB buffer, using an automated hammer. Extracted sap was incubated at $65^{\circ} \mathrm{C}$ and then chloroform treated. TNA was precipitated with 0.6 volume of cold 2-isopropanol and resuspended in $120 \mu \mathrm{L}$ of sterile water for PCR assays.

Reverse transcription (RT) and polymerase chain reaction (PCR)

Samples were assayed by RT-PCR for the presence of seven olive viruses, including ArMV, CLRV, CMV, OLRSV, OLV-1, OLYaV and SLRSV. Virus RNAs were reverse transcribed using $200 \mathrm{U}$ of Moloney Murine Leukaemia virus reverse transcriptase enzyme (Invitrogen Corporation), $4 \mu \mathrm{L}$ of $5 \mathrm{XFS}$ M-MLV buffer, $2 \mu \mathrm{L}$ of DTT $(0.1 \mathrm{M})$, and $0.5 \mu \mathrm{L}$ of dNTPs $(10 \mathrm{mM})$. The mixture was incubated at $39^{\circ} \mathrm{C}$ for $1 \mathrm{~h}$ and then at $70^{\circ} \mathrm{C}$ for 10 min. PCR was performed using $2.5 \mu \mathrm{L}$ of cDNA, together with $2.5 \mu \mathrm{L}$ of $10 \times$ Taq polymerase buffer (Promega Corporation), $1 \mu \mathrm{L}$ of $25 \mathrm{mM} \mathrm{MgCl}_{2}, 0.5 \mu \mathrm{L}$ of $10 \mathrm{mM}$ dNTPs, $0.5 \mu \mathrm{L}$ of $10 \mu \mathrm{M}$ of sense and antisense primers (Table 2) and 1 unit of Taq DNA polymerase $\left(5 \mathrm{U}^{-1} \mathrm{~L}^{-1}\right)$ in a final volume of $25 \mu \mathrm{L}$. Amplifications were carried out in a thermocycler (Biometra) after a preliminary denaturation at $94^{\circ} \mathrm{C}$ for $4 \mathrm{~min}$, followed by 35 cycles at $94^{\circ} \mathrm{C}$ for $35 \mathrm{~s}$, annealing at $55^{\circ} \mathrm{C}$ for $35 \mathrm{~s}\left(58^{\circ} \mathrm{C}\right.$ for OLYaV) and $72^{\circ} \mathrm{C}$ for $35 \mathrm{~s}$, and a final extension step at $72^{\circ} \mathrm{C}$ for $7 \mathrm{~min}$. Amplified products were electrophoresed in 5\% TBE polyacrylamide gel (PAGE) and visualized by silver nitrate staining.

DNA was extracted from olive samples following the CTAB protocol and assayed by PCR using primers RST31/33, which are widely used in the detection of different Xf subspecies (Minsavage et al., 1994). Reactions consisted of a $1 \times$ amplification buffer in a final volume of $25 \mu \mathrm{L}$, containing $2.5 \mu \mathrm{L}$ of TNA, $1 \mu \mathrm{L}$ of dNTPs $(10 \mathrm{mM}), 0.5 \mu \mathrm{L}$ of each sense and antisense primers $(10 \mu \mathrm{M})$, and $1.25 \mathrm{U}$ of Taq DNA polymerase. PCR cycles consisted of $94^{\circ} \mathrm{C}$ for $1 \mathrm{~min}$ followed by 40 cycles of $94^{\circ} \mathrm{C}$ for $30 \mathrm{~s}, 55^{\circ} \mathrm{C}$ for $30 \mathrm{~s}$, and $72^{\circ} \mathrm{C}$ for $45 \mathrm{~s}$, and a final step of $72^{\circ} \mathrm{C}$ for $5 \mathrm{~min}$. PCR reactions were electrophoresed in $1.2 \%$ TAE agarose gels.

\section{Cloning, sequencing and bioinformatic analyses}

Based on the occurrence of each virus in the tested samples, amplified RT-PCR products yielded from different infected olive trees were transformed in StrataClo$\mathrm{ne}^{\mathrm{TM}}$ PCR Cloning vector pSC-A (Stratagene), subcloned into Escherichia coli DH5a cells, and three DNA clones from each sample were custom sequenced bidirectionally (Eurofins Genomics). Nucleotide sequences were analyzed with the DNA Strider 1.1 program (Marck, 1988). Multiple alignments of nucleotide sequences were performed using the default options of CLUSTALX 1.8 (Thompson et al., 1997). The BLASTn program was used to search for nucleotide homology in GenBank (Altschul et al., 1990). Tentative phylogenetic trees were constructed with the MEGA 6 version software, using the Neighbor-joining method, with 1000 bootstrap replicates (Tamura et al., 2013).

\section{RESULTS AND DISCUSSION}

\section{Detection of olive viruses and Xylella fastidiosa}

RT-PCR detection of olive viruses showed that almost all the native Albanian olive cultivars tested were infected with a least with one virus (97.5\% of infection). Only one tree was virus-free. OLYaV was the most prevalent virus (in $85 \%$ of samples), followed by OLV- 1 in $50 \%$ of samples (Table 1). The high incidence of OLYaV in the sampled Albanian olive trees was similar to that reported in other countries, including Lebanon (24\%), Syria (15\%), Tunisia (49\%), Italy (42\%), and the United States of America (93\%) (Saponari et al., 2002; Albanese et al., 2003; Al Abdullah et al., 2005; Fadel et al., 2005; Faggioli et al., 2005; Al Rwahnih et al., 2011; El Air et al., 2011). The transmission of this virus occurs through the exchange of infected plant propagation material; however, it is strongly suspected that the olive psyllid (Euphyllura olivinae), which has been repeatedly found to host OLYaV, is the vector of this virus in nature, although this has not been demonstrated with experimental transmission tests (Sabanadzovic et al., 1999). For this reason, it is difficult to establish which path OLYaV has taken in the varietal collection plot to reach such high incidence.

OLV-1 is a polyphagous soilborne virus capable of infecting crops without being transmitted by vectors. These two characteristics make this virus very transmissible. OLV-1 has also been shown to be present in blossoms (Lobão et al., 2002), pollen (Saponari et al., 2002), and fruit pulp (Félix, unpublished) of infected trees, as well as in high proportions ( $>80 \%)$ of seedlings originating from infected olive trees (Saponari et al., 2002) 
Table 2. List of primers used in RT-PCR assays for detecting the olive-infecting viruses. CP, Coat protein; RdRP, RNA-dependent RNA Polymerase; HSP70-like protein, Heat shock protein $70 \mathrm{kDa}$-like protein.

\begin{tabular}{|c|c|c|c|c|c|}
\hline Virus & Genus & $\begin{array}{l}\text { Amplified } \\
\text { region }\end{array}$ & $\begin{array}{l}\text { Primer sequence } \\
\text { (5' to 3') }\end{array}$ & $\begin{array}{l}\text { Amplicon length } \\
\text { (bp) }\end{array}$ & Reference \\
\hline ArMV & Nepovirus & CP gene & $\begin{array}{l}\text { TTGGTTAGTGAATGGAACGG } \\
\text { TCAACTCACCCTCCAAATCCC }\end{array}$ & 504 & Grieco et al., 2000 \\
\hline CLRV & Nepovirus & CP gene & $\begin{array}{l}\text { TTGGCGACCGTGTAACGGCA } \\
\text { GTCGGAAAGATTACGTAAAAGG }\end{array}$ & 416 & Faggioli et al., 2005 \\
\hline OLRSV & Nepovirus & 3'terminal & $\begin{array}{l}\text { TTGCAAAACTAGTGCCAGAGG } \\
\text { TGCATAAGGCTCACAGGAG }\end{array}$ & 480 & Grieco et al., 2000 \\
\hline CMV & Cucumovirus & RdRP gene & $\begin{array}{l}\text { TAACCTCCCAGTTCTCACCGT } \\
\text { CCATCACCTTAGCTTCCATGT }\end{array}$ & 513 & Grieco et al., 2000 \\
\hline OLV-1 & Alphanecrovirus & 3'terminal & $\begin{array}{l}\text { ACACAGAAATCATAAGTGCC } \\
\text { CCATAGCACCATCATACC }\end{array}$ & 299 & Faggioli et al., 2005 \\
\hline OLYaV & Closterovirus & HSP70 gene & $\begin{array}{l}\text { CGAAGAGAGCGGCTGAAGGCTC } \\
\text { GGGACGGTTACGGTCGAGAGG }\end{array}$ & 383 & Sabanadzovic et al., 1999 \\
\hline SLRSV & Sadwavirus & CP gene & $\begin{array}{c}\text { CCCTTGGTTACTTTTACCTCCTCATTGTCC } \\
\text { AGGCTCAAGAAAACACAC }\end{array}$ & 293 & Faggioli et al., 2005 \\
\hline
\end{tabular}

indication transmission through seeds. By means of ovule fertilization with infected pollen andlor by grafting of cultivar plants that are 'recalcitrant' to rooting onto seedlings originated from infected seeds, all these approaches make again OLV-1 a very infectious virus. Factors favouring the high OLV-1 incidence in the olive trees of Valias field merits future investigation.

The OLRSV incidence particularly high (48\%) compared with olive orchards in other Mediterranean countries, i.e., Tunisia (17\%), Lebanon (14\%), and Syria $12 \%$ (El Air et al., 2011; Al Abdullah et al., 2005; Fadel et al., 2005). No vector for OLRSV is known; however, as a nepovirus, its natural transmission could occur through nematodes. These pests have not been reported from the Valias collection plot, suggesting that the transmission of OLRSV may have occurred through infected self-rooted olive tree cuttings.

Among the viruses tested, CMV was the third most commonly found ( $28 \%$ of the samples). This incidence is similar to reports from other countries, i.e., Syria (23\%) and Tunisia (26\%) (Al Abdullah et al., 2005; El Air et al., 2011). Although CMV is transmitted through many different aphid vectors (Myzus spp.), the presence in Albanian olive cultivars may not be attributed to these, because their association with olive has not been demonstrated.

SLRSV and CLRV were found at low incidence, i.e., $1 \%$ for SLRV and 3\% for CLRV, and ArMV was not detected. The rare presencelabsence of these three polyphagous neopoviruses in Albanian olives is satisfactory.

Excluding the OLYaV infections, whose investigation on olive plants is regulated on the basis of a simple visual inspection for the presence of leaf yellowing symp- toms (EU Directives n'. 2016/97 for “CAC” [Conformitas Agraria Communitatis] category), and not on laboratory tests as conducted in the present study, the phytosanitary status of the 14 native Albanian cultivars tested here can be considered as acceptable.

A high proportion (93\%) of the tested olive plants material was free of ArMV, CLRV, SLRSV, and symptoms of yellowing of the leaves. It is therefore legitimate to classify the plants as "CAC" category. The presence of OLYaV found in the samples based on laboratory tests is worrying, because the latent period of this virus in the infected plant material is unpredictable. For phytosanitary safety, therefore, this material should be excluded from the "CAC" category in the future Albanian certification programme. Consequently, five trees of three 3 native varieties and one foreign cultivar ('Leccino') were eligible for the "CAC" category. Only one plant of the native cultivar 'Ulliri i kuq' was found free of all the viruses tested, so this plant can be designated in the "Virus-tested" plant material category. For the remaining olive cultivars, for which no virus-free plants were detected, sanitation measures (thermotherapy andlor in vitro shoot tip culture), or sanitary selections for a greater number of olive plants, are recommended for the future certification programme in Albania. It is notable that attempts to correlate the presence of any single virus or group of viruses with specific host symptoms in Valias plot were unsuccessful. This agrees with other reports on the symptomatology of these viruses (Martelli, 2013).

PCR results showed that Xf was not present in any of the tested samples, confirming previous reports of absence of this pathogen in Albania (Cara et al., 2016). 


\section{Sequence variability}

All of the virus sequences obtained in this study were deposited in the GenBank under different accession numbers $\left(\operatorname{acc} . n^{\circ}\right)$, and are shown in the phylogenetic trees (Figure 1). The sequence of SLRSV found only in one Albanian olive tree of cultivar 'I Bardhi i Tiranes' (isolate I Bardhi3) had $80.5 \%$ to $93.5 \%$ similarity with those in GenBank; whereas two isolates $G r \backslash T s$ and $G r\rangle$ Ms (acc. $n^{\circ}$, respectively, MK936233 and 706532), were recently identified in olive trees in Greece (Manthoudiakis et al., 2020), and these were the most related isolates (93.5\% similarity). The SLRSV isolates present in the Genbank database showed $22 \%$ of variability, in the coat protein homologue region investigated here.

The sequence analyses of CLRV isolates found in two Albanian olive cultivars, i.e., 'Krypsi' and 'Kokermadhi', showed, respectively, $86 \%$ and $87 \%$ to $98 \%$ similarity with homologue isolates in the database. Both SLRSV isolates (Krypsi 2 and Kokermadhi 4) shared 98.2\% similarity with the Adilcevaz isolate from Turkey (acc. $n^{\circ}$
FJ785323), and $G r \backslash G d$ (acc.n ${ }^{\circ}$ MK936236) and $G r \backslash \operatorname{Tr}$ (acc. $\mathrm{n}^{\circ}$ MK936235) from Greece, whereas the sequence similarity between the two SLRSV isolates was $96 \%$.

The incidence of OLV-1 was greater than that of SLRSV and CLRV; thus, 11 isolates, i.e., one from each OLV1-infected cultivar (Table 1), were chosen for sequencing. The comparison of their sequences showed three different representative sequence-types of all 11 OLV-1 isolates that were present as single infections in cultivars 'Kokermadhi', 'Kushan' and 'Mixan', and in mixed virus infections. Albanian OLV-1 isolates shared $88 \%$ to $98.3 \%$ similarity with those of the GenBank. Whereas isolate Kushan 3 had similarity of $98.3 \%$ with isolate V10 from Portugal (acc.n $n^{\circ} \mathrm{KF} 804063$ ), isolate Kokermadhi3 had $96 \%$ similarity with $P 33$ (acc.n MN586597, from Tunisia), and Mixan2 had 97\% similarity with G1A (acc.n KF804056, from Portugal).The Albanian OLV-1 isolates showed $93.3 \%$ and $98 \%$ similarity.

In the case of OLYaV, one isolate from each of the 15 OLYaV-infected cultivars was sequenced. After the sequence analysis, seven different sequence-types were (a)

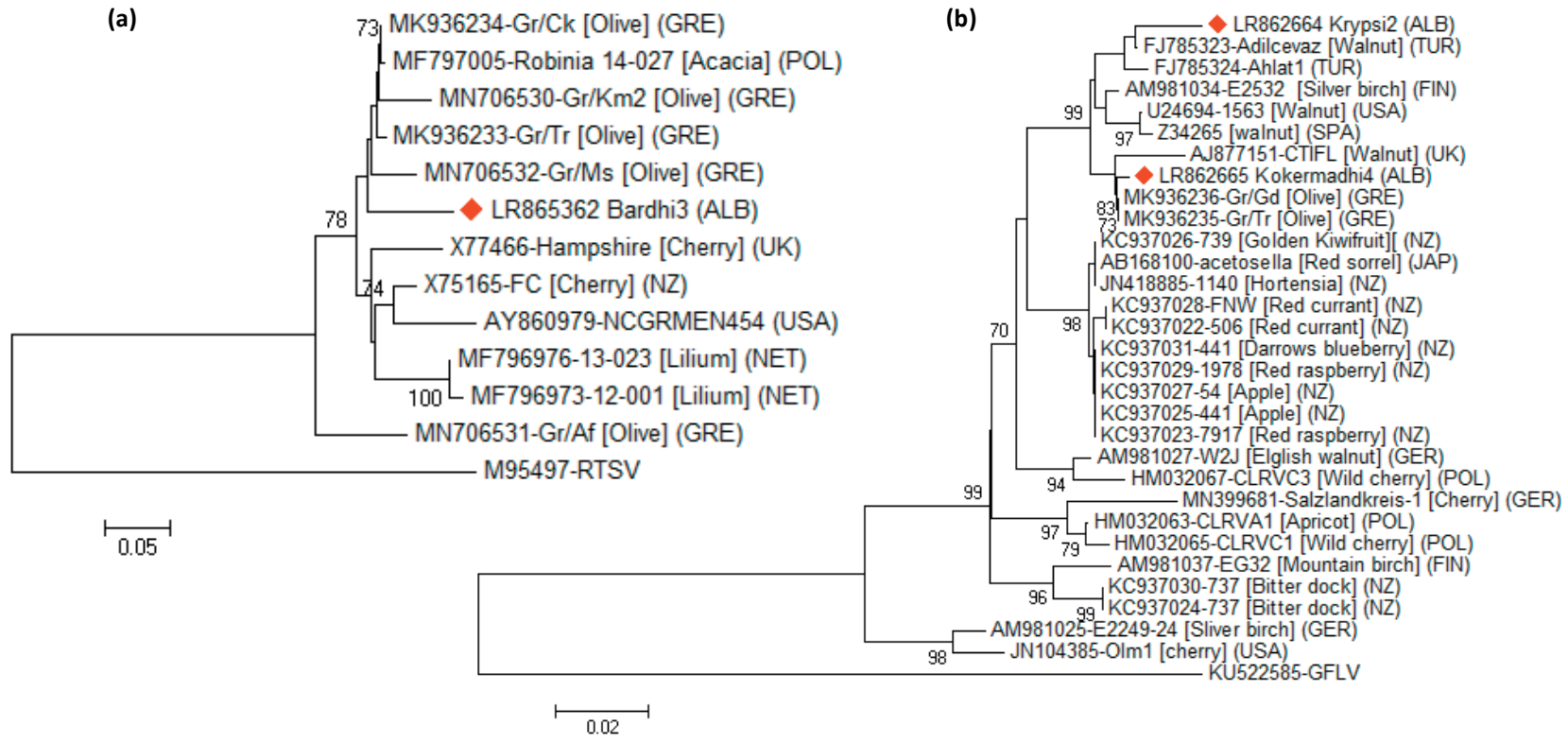

Figure 1. Phylogenetic trees based on nucleotide sequences of different partial genes\domains of SLRSV (a), CLRV (b), OLV-1 (c), CMV (d) and OLYaV (e). Alignments were obtained using Clustal X 1.8, and analyzed by the Neighbor-Joining method with 1000 bootstrap replicates. The percentage of replicate trees (when $>70 \%$ ) in which the virus isolates clustered together is shown next to each branch. GenBank accession number, name, isolation sources and countries of origin of each corresponding virus isolate used in the analysis are reported in the phylogenetic tree. Rice tungro spherical virus (RTSV) of the genus Waikavirus, Grapevine fanleaf virus (GFLV) of the genus Nepovirus, Olive mild mosaic virus (OMMV) of the genus Alphanecrovirus, Fig mosaic virus (FMV) of the genus Emaravirus and Daucus carota HSP70 gene, were used as outgroup species. The abbreviations used for countries of origin of the isolates are: Albania (ALB); Australia (AUS); Chile (CHI); Croatia (CROA); Egypt (EGY); Finland (FIN); France (FRA); Germany (GER); Greece (GRE); India (IND); Israel (ISR); Italy (ITA); Japan (JAP); Malaysia (MAL); Netherlands (NET); New Zealand (NZ); Palestine (PAL); Poland (POL), Portugal (PORT); South Korea (S-KOR); Spain (SPA); Tunisia (TUN); Turkey (TK); Uganda (UGA); United Kingdom (UK); and United States of America (USA). Albanian virus isolates are indicated in red. 
(c)

KF804058-G5A [Olive] (PORT) KF804057-G2A [Olive] (PORT) KF804055-C1VM [Olive] (PORT) KF804053-G3S [Olive] (PORT) KF804067-Croatia1 [Olive] (CROA) KF804068-Croatia2 [Olive] (CROA) KF804065-OlivMitra [Olive] (PORT) KF804066-A1P2 [Olive] (PORT) KF804051-G1PB [Olive] (PORT) KF804059-G8M [Olive] (PORT) KF804052-G1S [Olive] (PORT) [ KF804062-V6 [Olive] (PORT) DQ083996-GM6 [Olive] (PORT)

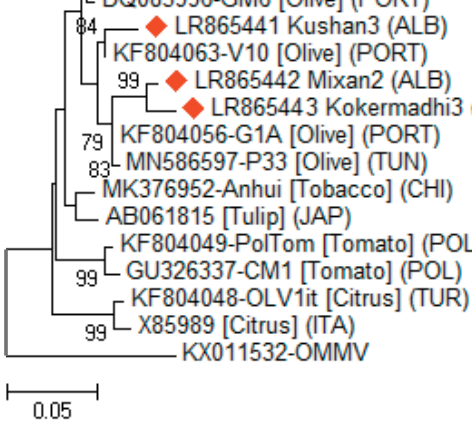

(d)

—MN495619-MKCMR2 [Chilli] (IND) 99. MN495618-ATCMV2 [Chilli] (IND) 78 LR865402 Kalinjot3 (ALB)

LR865403 Krypsi2 (ALB) 100 KU947030-AT2 [Black pepper] (IND) - LR865404 Mixan3 (ALB) 100 KM272278-KO [Black pepper] (IND) — KT921315-HM3 [Tomato] (EGY) - JN054637-CLW2 [Cucumber] (MAL) AF150731-cds [Cucumber] (GER) - LC066466-IRN-REY4 [Radish] (CHI) L KP165581-PV0187 [Cucumber] (GER) 99 KC527685-RP1 [Pepper] (S-KOR)

78 [LC66454-YMD068J [Pepper] (JAP) — LC066415-MD965J [Radish] (JAP)

100 MG021461-Ug92 [Americam taro] (UGA)

MG021458-Ug91 [Americam taro] (UGA)

— KY794709-Met [Potato] (CHI)

— DQ785470-pCb7 [Tomato] (CHI)

- KC527728-RP49 [Pepper] (S-KOR)

96 KC527710-RP27 [Pepper] (S-KOR)

95 L DQ785469-pRad35 [Radish] (CHI) 7 (7) KC527724-RP45 [Pepper] (S-KOR) 99 KC527723-RP44 [Pepper] (S-KOR) 89 MN422337-GTN [Pepper] (S-KOR) LC510820-Ca-Ch1 [Pepper] (S-KOR) 0.05

(e)

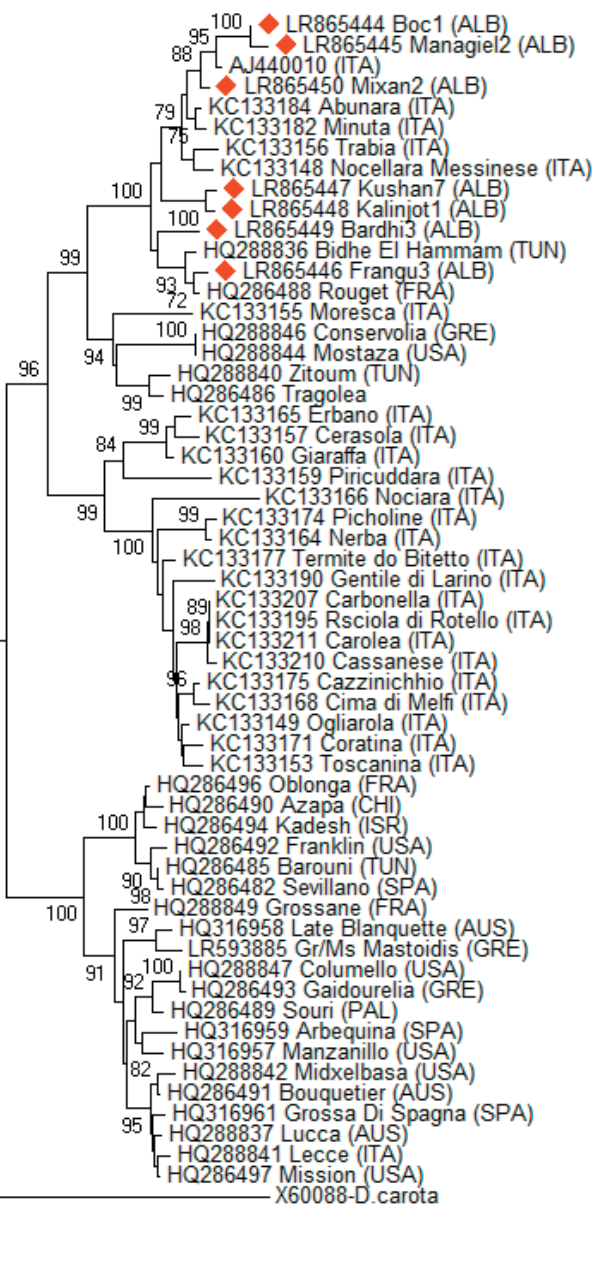

Figure 1. Continued. 
identified, sharing $88.2 \%$ to $98.6 \%$ similarity. BLASTn sequence analysis showed that isolate Mangiel2 was the most variable among the Albanian isolates and with those of the GenBank, with sequence similarity of $69.9 \%$. Opposite to this, greatest similarity was found with Frangu3 isolate that showed $98.9 \%$ similarity with GenBank isolates. In general, the similarity margin, comparing the sequences of the seven Albanian isolates with those in Genbank, ranged from 90.3\% (Bardhi3) to $98.9 \%$ (Frangu3). In particular, isolates Boç1 and Mangiel2 had the greatest similarity (respectively, 97.1\% and 96\%) with the Italian isolate $A J$ (acc. $\mathrm{n}^{\circ}$ AJ440010). Mixan 2 shared $97.9 \%$ similarity with isolate Abunara from Tunisia (acc. $\mathrm{n}^{\circ} \mathrm{KC133184)}$ ). Of the three OLYaV isolates, Kushan7 had $93.7 \%$ similarity with isolate Rouget (acc.n ${ }^{\circ}$ HQ286488, from France), Kalinjot1 had 92.4\% similarity with Bidhel Hammam (acc.n ${ }^{\circ}$ HQ288836, from Tunisia), and Frangu 3 had $98.9 \%$ similarity with Nocellara messinese (acc. $\mathrm{n}^{\circ} \mathrm{KC1} 33148$, from Italy).

Nine Albanian olive cultivars were shown to be infected with OLRSV, so their RT-PCR amplicons were sequenced. BLASTn analyses of obtained sequences (acc. $n^{\circ}$ LR865438, isolate Kalinjot3; LR865403, isolate Krypsi2; and LR865404, Mixan3) showed that these isolates shared $99.1 \%$ to $99.3 \%$ similarity with the unique OLRSV isolate in the GenBank (acc.n NC_038863); whereas the intraspecies variability ranged from $0.9 \%$ to $1.5 \%$.

Five Albanian cultivars were infected with $\mathrm{CMV}$ (Table 1), so their RT-PCR amplicons were sequenced. Nucleotides sequence comparison for these isolates showed three different sequence types, found as single infections in the olive cultivars 'Kalinjot', 'Krypsi' and 'Mixan'. The sequence from 'Kalinjot' shared $89.8 \%$ to 99.4\% similarity with the homologue from the GenBank, that from 'Krypsi' was $89.0 \%$ to $99.2 \%$ similar, and the sequence from 'Mixan' was $87.8 \%$ to $98.8 \%$. The Albanian isolates were $93.3 \%$ to $96.1 \%$ similar to each other. The CMV sequences of the other two infected cultivars ('Kokermadhi' and 'Frantoio Valias') were identical to that of the isolate from 'Kalinjot'.

\section{Phylogenetic analyses}

The phylogenetic analyses conducted in this study aimed to determine relationships between viruses found in the Albanian olive cultivars and their homologues of international origins. In the case of SLRSV, the analysis was conducted on the few sequences of isolates from olive reported in the GenBank, together with those from other crops. In the phylogenetic tree, the Albanian isolate of SLRSV (Bardhi3) clustered in one clade together with Greek isolates from olive ( $G r \backslash T r, G r \backslash M s$ and $G r \backslash$ $\mathrm{km} 2$ ) (Figure 1a). A similar clustering was found for CLRV isolates from Albania, i.e., Kokermadhi4, that grouped together with olive isolates from Greece $(G r \mid G d$, $G r \backslash T r$ ). In contrast, Krypsi2 clustered closely to Adilcevaz and Ahlat1 isolates, both reported from walnuts in Turkey (Figure $1 b$ ).

The OLV-1 phylogenetic tree had four differentiated clusters based on infected hosts rather than geographic origins. The largest cluster was composed of isolates from olive from Portugal, for which the Albanian isolates Kokermadhi2, Kushan 3 and Mixan2 were part of in a distinct clade (Figure 1c).

Analogous to SLRSV, the lack of CMV sequences from olive in GenBank conditioned the phylogenetic analysis that was based on isolates from different crops rather than on those from olive. The phylogenetic tree for CMV isolates did not show any distribution, based on host species and \or geographic origin. However, the Albanian isolates from olive formed one clade with those from chili and black pepper from India (Figure 1d). It is likely that this indistinct distribution of CMV isolates in the phylogenetic tree was conditioned by the polyphagous nature of this virus, exposing it to sequence recombination that has generated a quasi-species which is difficult to be differentiated by phylogenetic analysis.

The presence of a single for OLRSV sequence in GenBank has limited the design of a phylogenetic scenario for this virus. The present analysis was therefore limited, only reporting the genetic variability found among the three isolates that were sequenced.

The phylogenetic tree of OLYaV showed two clusters, one which was diversified with isolates from different origins, i.e., the United States of America, Australia, Chile, France, Greece, Italy, Israel, Palestine, Spain, and Tunisia, while the second was composed of Mediterranean isolates, i.e., from France, Greece, Italy, and Tunisia. The exception was isolate from the United States of America, which has a Spanish denomination (cultivar 'Morteza'). The Albanian isolates all grouped together in a clade close to Italian isolates.

\section{CONCLUSIONS}

This study was carried out to identify a "Virusfree", or at least "Virus-tested", plant material that could be part of primary resources for a future certification programme for olive in Albania. This research is not unique, because two decades ago, two similar investigations were conducted in this country to identify possible virus infections in native olive trees, using double- 
stranded RNA analyses (Çakalli et al., 2006; Saponari et al., 2002). Both investigations reported a virus incidence of 22 to $24 \%$; but did not specify the identity of the viruses in the Albanian olive cultivars. Eight years later, a third investigation was undertaken on 50 olive trees, and this reported the presence of only two viruses i.e., SLRSV and OLYaV in a few olive cultivars (Luigi et al., 2009). Excluding these three investigations, little is known of the occurrence and distribution of other viruses that may be present in Albanian olive cultivars.

The present study reports for the first time the presence of four viruses (CLRV, OLRSV, OLV-1 and $\mathrm{CMV}$ ) in the most important Albanian olive cultivars. Although the number of samples tested was limited and does not allow a comprehensive definition of the incidence of these viruses as only the Valias collection plot was assayed, discovery of these viruses in most of the 14 cultivars is of great concern. This is particularly because these native cultivars are pomologically and phenotypically important and are likely to be part of the future olive certification programme in Albania.

This study identified five olive trees of three native cultivars ('Managiel', 'Kalinjot' and 'Kushan-Preze') and one foreign cultivar ('Leccino') that were found free of ArMV, SLRSV, CLRV and OLYaV, and one olive tree of cultivar 'Uliri i Kuq-Preze' that was free of all the tested viruses. Based on EU directives (EU n ${ }^{\circ}$. 2016/97 for the category "CAC" [Conformitas Agraria Communitatis]), the plant material of these Albanian cultivars, found in the phytosanitary categories "CAC" and "Virus-tested", are valuable candidate clones that can be used in the propagation of high quality material in the future olive certification programme. At the genome level, all the viruses found in the Albanian cultivars presented low genetic variability, compared to that reported from other Mediterranean countries (Mathioudakis et al., 2020; Al Rwahnih et al., 2011; El Air et al., 2011; Essakhi et al., 2006; Al Abdullah et al., 2005). The limited exchange of olive plant material in the Balkan area, in particular of Albanian native olives, has preserved the phytosanitary status of this material from the introduction of international viruses isolates. Further laboratory analyses should be carried out on more olive clones, and on cultivars not tested in this study, to identify healthy candidates that could be part of a future olive certification programme in Albania.

\section{ACKNOWLEDGMENT}

This research was conducted in the framework of the project "Sustainable development of the olive sector in Albania - ASDO", as part of the "Program for the modernization of the agricultural sector - PROMAS" funded by the Albanian Ministry of Agriculture and Rural Development and by the Italian Agency for Development Cooperation (AICS) of the Ministry of Foreign Affairs and International Cooperation.

\section{LITERATURE CITED}

Al Abdullah A, Elbeaino T, Saponari M, Hallakand M., 2005. Preliminary evaluation of the status of oliveinfecting viruses in Syria. EPPO Bulletin 35: 249-252.

Albanese G., Faggioli F., Ferretti L., Sciarroni R., La Rosa R., Barba M., 2003. Sanitary status evaluation of olive cultivars in Calabria and Sicily. Journal of Plant Pathology 85: 304.

Al Rwahnih M., Guo Y., Daubert S., Golino D., Rowhani A., 2011. Characterization of latent viral infection of olive trees in the national clonal germplasm repository in California. Journal of Plant Pathology 93: 227231.

Altschul S.F., Stephen F., Gish W., Miller W., Myers E.W., Lipman D.J., 1990. Basic local alignment search tool. Journal of Molecular Biology 215: 403-410.

Belaj A., Satovic Z., Ismaili H., Panajoti D., Dallo L., Trujillo I., 2003. RAPD genetic diversity of Albanian olive germplasm and its relationships with other Mediterranean countries. Euphytica 130: 387-395.

Çakalli A., Myrta A., Savino V., Kullaj E., Shahini S... Ruci, T., 2006. Applying of dsRNA isolation test for identification of viruses on the main Albanian olive native varieties. Yearbook of Plant Protection Society of the Republic of Macedonia, Vol. XVII, p. 63.

Cara M., Merkuri J., Koka E., Bacaj M., Cara O., 2016. Xylella fastidiosa does not occur in Albania: Preliminary results. Journal of Multidisciplinary Engineering Science and Technology 3(10): 5701-5705.

El Air M., Mahfoudhi N., Digiaro M., Najjar A., Elbeaino T., 2011. Detection of olive-infecting viruses in Tunisia. Journal of Phytopathology 159: 283-286.

Essakhi S., Elbeaino T., Digiaro M., Saponari M., Martelli G.P., 2006. Nucleotide sequence variations in the HSP70 gene of Olive leaf yellowing-associated virus. Journal of Plant Pathology 88: 285-291.

Fadel C., Digiaro M., Choueiri E., Elbeaino T., Saponari M...Martelli G.P., 2005. On the presence and distribution of olive viruses in Lebanon. EPPO Bulletin 35: 33-36.

Faggioli F., Ferretti L., Albanese G., Sciarroni R., Pasquini G.,... Barba M., 2005. Distribution of olive tree viruses in Italy as revealed by one-step RT-PCR. Journal of Plant Pathology 87: 45-51. 
Foissac X., Svanella-Dumas L., Gentit P., Dulucq M.J., Candresse T., 2001. Polyvalent detection of fruit tree tricho-, capillo- and foveaviruses by nested RT-PCR using degenerate and inosine containing primers (DOP RT-PCR). Acta Horticulturae 550: 37-43.

Grieco F., Alkowni R., Saponari M., Savino V., Martelli G.P., 2000. Molecular detection of olive viruses. EPPO Bulletin 30: 469-473.

Hendson M., Purcell A.H., Chen D., Smart C., Guilhabert M., Kirkpatrick B., 2001. Genetic diversity of Pierce's disease strain and other pathotypes of Xylella fastidiosa. Applied Environmental Microbiology 67: 895-903.

Ismaili H., 2009. Study on the condition and production of olive plant material in Albania. Conference: MBUMK: "Olive development project in Albania" National Conference. July 2009.

Kolaj R., Ozuni E., Skunca D., Zahoalia D., 2017. The challenges of collective action for olive growers in Albania. European Journal of Interdisciplinary Studies 7: 93-98.

Lazemetaj L., 2018. The sector of olive oil production in Albania, achievements and challenges in future. International Journal of Advanced Research and Innovative Ideas in Education I (4): 2395-4396.

Lobão D.L., Félix M.R., Clara M.I.E., Oliveira S., Leitão F.A., Serrano J.F., 2002. Detection of Olive latent virus 1 in Olea europaea L. tissues by reverse transcription-polymerase chain reaction. XIII Congresso Nacional de Bioquimíca, Lisboa, Portugal, p 102.

Luigi M., Manglli A., Thomaj F., Buonaurio R., Barba M., Faggioli F., 2009. Phytosanitary evaluation of olive germplasm in Albania. Phytopathologia Mediterranea 48: $280-284$.

MAFCP., 2009. Study on the actual situation of olive orchards and the perspectives of its development. Ministry of Agriculture, Food and Consumer Protection. Tirana, Albania. (In Albanian).

Mathioudakis M.M., Saponari M., Hasiów-Jaroszewska B., Elbeaino T., Koubouris G., 2020. Detection of viruses in the major olive tree cultivars of Greece using a rapid and effective RNA extraction method toward the certification of virus-tested propagation material. Phytopathologia Mediterranea 59: 203-211.

Marck, C., 1988. DNA Strider: a C program for the fast analysis of DNA and protein sequences on the Apple Macintosh family computers. Nucleic Acids Research 16: 1829-1836.

Martelli G.P., 2013. A brief outline of infectious diseases of olive. Palestine Technical University Research Journal 1(1): 1-9

Ministry of Agriculture - Statistical Yearbook, 2017. Statistical Processing: INSTAT.
Minsavage G.V., Thompson C.M., Hopkins D.L., Leite M.V.B.C., Stall R.E., 1994. Development of a polymerase chain reaction protocol for detection of Xylella fastidiosa in plant tissue. Phytopathology 84: 456-461.

Sabanadzovic S., Abou-Ghanem N., La Notte P., Savino V., Scarito G., Martelli G.P., 1999. Partial molecular characterization and RT-PCR detection of a putative closterovirus associated with leaf yellowing. Journal of Plant Pathology 81: 37-45.

Saponari M., Alkowni R., Grieco F., Driouech N., Hassan M., Di Terlizzi B., 2002. Detection of Olive-infecting virus in the Mediterranean basin. Acta Horticulturae 586: 787-790.

Saponari M., Boscia D., Nigro F., Martelli G.P., 2013. Identification of DNA sequences related to Xylella fastidiosa in oleander, almond and olive trees exhibiting leaf scorch symptoms in Apulia (Southern Italy). Journal of Plant Pathology 95: 668.

Tamura K., Stecher G., Peterson D., Filipski A., Kumar S., 2013. MEGA6: Molecular Evolutionary Genetics Analysis version 6.0. Molecular Biology and Evolution 30: 2725-2729.

Thompson J.D., Gibson T.J., Plewniak F., Jeanmougin F., Higgins D.G., 1997. The CLUSTAL X windows interface: flexible strategies for multiple sequence alignment aided by quality analysis tools. Nucleic Acids Research 25: 4876-4882.

Velo S., Topi D., 2017. The production potential of the olive oil from native cultivars in Albania. International Journal of Engineering Research \& Science 3: 38-43. 